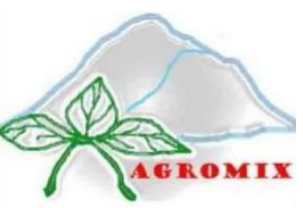

\title{
AGROMIX
}

Jurnal IImiah Fakultas Pertanian, Universitas Yudharta Pasuruan pISSN (Print): 2085-241X; elSSN (Online): 2599-3003

Website: https://jurnal.yudharta.ac.id/v2/index.php/agromix

\section{Analisis faktor-faktor yang mempengaruhi motivasi penyuluh pertanian di era revolusi industri 4.0}

Analysis of the factors that influence the motivation of agricultural extension workers in the era of the industrial revolution 4.0

Sugino ${ }^{1^{*}}$

${ }^{1}$ Universitas Brawijaya, Malang, Jawa Timur

*Email korespondensi: ssugino64@gmail.com

\section{ABSTRACT}

\section{Article History}

Received : July 1, 2020

Accepted : February 2, 2021

Published : March 30, 2021

\section{Keyword}

path analysis; external factors; competency factors; driving

factors; inhibiting factors
The motivation of agricultural instructors can be influenced by driving factors, inhibiting factors, external factors, and instructor competency factors. This study aims to analyze the factors of work motivation in the industrial revolution 4.0 era. The research chose Batu City, Malang City, and Malang Regency as study areas. The population is all extension workers who have civil servant status, whether the skilled or expert level in the study area, as many as 149 instructors. Determination of the sample using the Slovin formula with a confidence level of $10 \%$ which resulted in 98 respondents and selected by purposive sampling. Primary data collection in the form of a survey for respondents who produced interval data on a Likert scale. Achievement analysis supports the path analysis supported by the SPSS Version 21 application in completing its statistical calculations. The study found that the driving factors and inhibiting factors did not directly influence the motivation of the instructor. While external factors and competency factors have a direct influence on instructor motivation.

\section{Riwayat Artikel \\ Dikirim : 1 Juli 2020 \\ Disetujui : 2 Pebruari 2021 \\ Diterbitkan : 30 Maret 2021 \\ Kata Kunci \\ analisis jalur; faktor eksternal; faktor kompetensi; faktor pendorong; faktor penghambat}

\section{ABSTRAK}

Motivasi penyuluh pertanian dapat dipengaruhi oleh faktor pendorong, faktor penghambat, faktor eksternal, dan faktor kompetensi penyuluh. Penelitian ini mempunyai tujuan untuk menganalisis pengaruh faktor-faktor terhadap motivasi kerja penyuluh di era revolusi industri 4.0. Penelitian memilih Kota Batu, Kota Malang, dan Kabupaten Malang sebagai wilayah studi. Populasi merupakan seluruh penyuluh yang mempunyai status PNS baik tingkat terampil maupun ahli di wilayah studi sebanyak 149 penyuluh. Penentuan sampel menggunakan rumus Slovin dengan tingkat kepercayaan $10 \%$ yang menghasilkan 98 penyuluh sebagai responden dan dipilih secara purposive sampling. Pengambilan data primer melibatkan form survei kepada responden yang menghasilkan data interval dalam skala Likert. Pencapaian tujuan memanfaatkan analisis jalur yang dibantu oleh aplikasi SPSS Versi 21 dalam menyelesaikan perhitungan statistiknya. Penelitian menemukan fakta bahwa faktor pendorong dan faktor penghambat tidak mempengaruhi secara langsung terhadap motivasi penyuluh. Sedangkan faktor eksternal dan faktor kompetensi penyuluh mempengaruhi secara langsung terhadap motivasi penyuluh.

Sitasi: Sugino. (2021). Analisis faktor-faktor yang mempengaruhi motivasi penyuluh pertanian di era revolusi industri 4.0. Agromix, 12(1), 7-16. https://doi.org/10.35891/agx.v12i1.2140

\section{PENDAHULUAN}

Penyuluhan pertanian merupakan suatu sistem pendidikan non-formal dalam bentuk pendidikan orang dewasa untuk meningkatkan pengetahuan maupun keterampilan petani dan masyarakat. Sasaran dari penyuluhan ini adalah sikap yang lebih baik dalam meningkatkan produksi usaha tani sesuai dengan potensi lokal. Penyuluh mempunyai peran untuk menyampaikan inovasi pertanian, menjadi penghubung antara masyarakat sasaran dengan pemerintah, pengusaha, perbankan, dan pemasaran (Bahua, 2016). Penyuluhan pertanian yang mempunyai makna mendasar bagi perubahan perilaku petani, terutama yang berhubungan dengan budidaya pertanian, pengolahan hasil dan pemasaran di era revolusi industri 4.0. Revolusi industri 4.0 ini telah berdampak besar terutama di bidang pertanian. Dampak itu terlihat dengan berbagai disrupsi mulai dari kecepatan dan kreativitas yang dapat menggantikan tenaga manusia maupun biodiversitasnya. Digitalisasi, bioteknologi, proses yang efektif merupakan kunci utama dari Revolusi industri 4.0 terhadap dunia pertanian. 
Penyuluh membutuhkan media penyuluhan agar tidak hanya mengandalkan pertemuan rutin dengan petani dan diskusi langsung. Media yang digunakan dapat berupa media cetak maupun elektronik (Roza dkk. 2018). Kemajuan TIK (Teknologi Informasi dan Komunikasi) menghadirkan peluang yang besar bagi pelaku pembangunan pertanian termasuk penyuluh pertanian (Setiawan 2015; Elian dkk. 2014; Sadono, 2008; Koys 2001). Penyuluh pertanian mempunyai pilihan untuk melakukan adaptasi dengan era revolusi industri 4.0. Pilihan tersebut melekat pada motivasi kerja penyuluh dalam melakukan tugas dan fungsinya. Motivasi kerja penyuluh membutuhkan dorongan untuk melakukan penyuluhan yang dapat menyebabkan petani atau masyarakat sasaran tergerak melakukan peningkatan produktivitasnya. Dorongan penyuluh untuk melakukan penyuluhan pada hakikatnya terselubung bagi yang bersangkutan, tetapi dapat ditelusuri melalui perilakunya. Hal ini sangat menarik untuk diungkap faktor-faktor yang terselubung bagi penyuluh yang mempengaruhi motivasi kerja penyuluh.

Beberapa peneliti terdahulu telah melakukan kajian yang berhubungan dengan kinerja penyuluh pertanian (Prasetyo dkk., 2020; Rochaeni, dkk. 2019, Sabir, dkk. 2018, Purwatiningsih, dkk., 2018; Roza dkk., 2018; Shen \& Li, 2017; Wicaksono, dkk., 2016; Fatchiya dan Amanah, 2016; Bahua, 2015). Peneliti-peneliti tersebut melaporkan faktorfaktor yang mempengaruhi kinerja penyuluh pertanian. Penelitian sejenis yang melibatkan teknologi informasi sebagai fokus kajian seperti: (1) pemanfaatan cyber extension melalui telepon genggam oleh petani anggrek di Taman Anggrek Ragunan, Jakarta Selatan (Dasli, dkk., 2015), (2) optimalisasi cyber extension dalam pembangunan pertanian di era MEA (Praza, 2016), (3) pemanfaatan internet dalam meningkatkan kinerja penyuluh pertanian di Kabupaten Cianjur (Purwatiningsih, dkk., 2018), (4) sikap afektif penyuluh terhadap website cyber extension sebagai sumber informasi penyuluhan pertanian di Kabupaten Karanganyar (Dzakiroh, dkk., 2018), (5) pemanfaatan informasi dan teknologi untuk meningkatkan kinerja agen penyuluh (Listiana dkk., 2019), (6) pemberdayaan petani (Mulyandari dkk., 2011).

Penelitian yang mengaitkan penyuluhan dengan pemberdayaan petani sudah banyak dilakukan oleh penelitipeneliti sebelumnya. Kajian-kajian tersebut mengkaji faktor-faktor yang mempengaruhi penyuluh pertanian dan merupakan sebagai obyek penelitian. Penelitian motivasi penyuluh pertanian yang memfokuskan penelitiannya pada penyesuaian di era atau masa pengabdiannya belum banyak dilakukan. Secara tegas, penelitian tentang motivasi kerja penyuluh pada masa revolusi industri 4.0 juga belum banyak dilakukan oleh peneliti sebelumnya. Kajian tentang motivasi penyuluh yang menghadapi masa revolusi industri 4.0 menarik untuk dikaji dan diteliti. Oleh karena itu, penelitian ini memfokuskan pada penelitian tentang motivasi penyuluh di masa revolusi industri 4.0. Secara khusus, penelitian ini mempunyai tujuan untuk menganalisis faktor-faktor yang mempengaruhi motivasi kerja penyuluh pertanian dalam melaksanakan tugasnya di era revolusi industri 4.0.

\section{METODE}

\section{Lokasi penelitian}

Penelitian ini mengambil wilayah administrasi di Kota Batu, Kota Malang, dan Kabupaten Malang Provinsi Jawa Timur (Gambar 1).
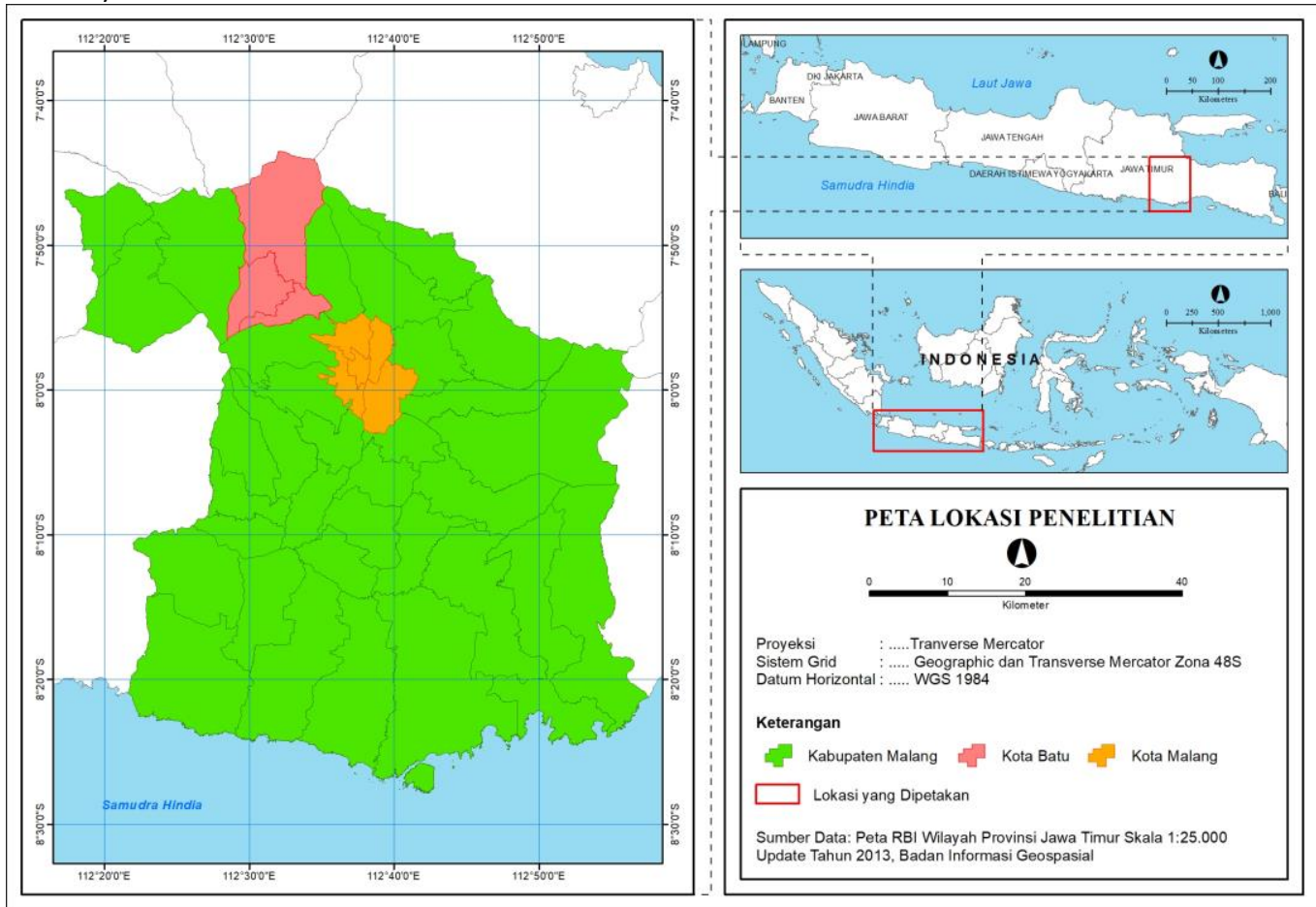

Gambar 1. Lokasi penelitian 


\section{Populasi dan penentuan ukuran sampel}

Populasi merupakan seluruh PNS yang mempunyai jabatan sebagai penyuluh pertanian dengan jenjang penyuluh ahli dan penyuluh terampil di Kabupaten Malang, Kota Malang, dan Kota Batu Provinsi Jawa Timur (Tabel 1). Pengambilan sampel menggunakan teknik purposive sampling dan perhitungan ukuran sampelnya menggunakan Rumus Slovin (Eq. 1). Hasil perhitungan ukuran sampel disajikan pada Tabel 1.

$$
\mathrm{n}=\frac{\mathrm{N}}{1+\mathrm{Ne}^{2}}
$$

Keterangan:

$n=$ ukuran sampel

$N=$ besarnya populasi

$e=$ besarnya deviasi yang dapat ditoleransi yaitu $10 \%$

Table 1. Jumlah populasi penyuluh dan jumlah sampel terpilih

\begin{tabular}{llcc}
\hline Jenjang Penyuluh & Lokasi & Populasi (penyuluh) & Sampel (responden) \\
\hline Ahli & Kota Batu & 22 & 18 \\
& Kota Malang & 20 & 17 \\
\multirow{3}{*}{ Terampil } & Kabupaten Malang & 89 & 47 \\
& Kota Batu & 2 & 2 \\
& Kota Malang & 2 & 2 \\
\hline Jumlah & Kabupaten Malang & 14 & 12 \\
\hline
\end{tabular}

\section{Data dan variable}

Pencapaian tujuan penelitian memanfaatkan data primer yang merupakan hasil rekapitulasi survey dari 98 responden. Analisis data melibatkan beberapa variabel (Tabel 2) yang diukur dengan skala likert (Tabel 3).

Tabel 2. Variabel yang digunakan dalam analisis data

\begin{tabular}{|c|c|c|c|}
\hline Variabel & Keterangan faktor & Variabel & Keterangan variabel \\
\hline \multirow[t]{6}{*}{$\mathrm{x} 1$} & Faktor pendorong & $\mathrm{x} 11$ & upah yang adil \\
\hline & & $x 12$ & kesempatan untuk maju \\
\hline & & $x 13$ & keamanan kerja \\
\hline & & $x 14$ & tempat kerja yang baik \\
\hline & & $x 15$ & perlakuan yang wajar \\
\hline & & $x 16$ & pengakuan atas prestasi \\
\hline \multirow[t]{3}{*}{$x 2$} & Faktor penghambat & $x 21$ & tidak ada penghargaan \\
\hline & & $x 22$ & tempat kerja yang tidak nyaman \\
\hline & & $x 23$ & tidak ada dukungan dari atasan \\
\hline \multirow[t]{5}{*}{$x 3$} & Faktor eksternal & $x 31$ & fasilitas kerja \\
\hline & & $x 32$ & dukungan administrasi \\
\hline & & x33 & kondisi lingkungan \\
\hline & & $x 34$ & keterjangkauan \\
\hline & & x35 & partisipasi masyarakat \\
\hline \multirow[t]{3}{*}{$x 4$} & Faktor kompetensi penyuluh & $x 41$ & penguasaan teknologi \\
\hline & & $x 42$ & pengetahuan \\
\hline & & $x 43$ & kreativitas \\
\hline \multirow[t]{2}{*}{ y1 } & Motivasi kerja penyuluh & y11 & dorongan berprestasi \\
\hline & & y12 & dorongan berafiliasi \\
\hline
\end{tabular}

Tabel 3. Skala Likert yang digunakan dalam penelitian ini

\begin{tabular}{|c|c|c|c|c|}
\hline \multirow{2}{*}{ Pernyataan } & \multicolumn{4}{|c|}{ Skala Likert } \\
\hline & 1 & 2 & 3 & 4 \\
\hline Mempengaruhi & Tidak mempengaruhi & Kurang mempengaruhi & Mempengaruhi & Sangat mempengaruhi \\
\hline Berkesempatan & Tidak berkesempatan & Kurang berkesempatan & Berkesempatan & Sangat berkesempatan \\
\hline Aman & Tidak aman & Kurang aman & Aman & Sangat aman \\
\hline Baik & Tidak baik & Kurang baik & Baik & Sangat baik \\
\hline Wajar & Tidak wajar & Kurang wajar & Wajar & Sangat wajar \\
\hline Ada pengakuan & Tidak ada pengakuan & Kurang ada pengakuan & Ada pengakuan & Sangat ada pengakuan \\
\hline
\end{tabular}




\section{Metode analisis data}

Analisis data melibatkan teknik analisis jalur (path analysis) yang penyelesaian hasilnya menggunakan Software SPSS Versi 21. Analisis jalur mempunyai kemampuan untuk menguji model keseluruhan dan parameter-parameter individual. Teknik analisis jalur juga mempunyai kemampuan untuk mengestimasi persamaan dalam melihat semua kemungkinan hubungan sebab akibat pada semua variable dalam model. Kemampuan melakukan dekomposisi korelasi menjadi hubungan yang bersifat sebab akibat (causal relation), seperti pengaruh langsung (direct effect) dan pengaruh tidak langsung (indirect effect) dan bukan sebab akibat (non-causal associatuion), seperti komponen semu (spurious) (Ghozali dan Fuad, 2008; Kline, 2011; Sarwono, 2012; Lo Choi Tung, 2011).

Tahapan analisis data mengikuti langkah-langkah yang telah dirumuskan oleh peneliti sebelumnya (Wijaya dkk., 2019; Khan dkk., 2019; Sarstedt \& Cheah, 2019; Sarwono, 2012; Kline, 2011; Lo Choi Tung, 2011) dan disesuaikan dengan tujuan penelitian.

1. Merancang hipotesis model pengaruh faktor-faktor (Tabel 3) terhadap motivasi kerja penyuluh pertanian (Gambar 2).

HO: Faktor pendorong, faktor penghambat, faktor eksternal, dan faktor kompetensi penyuluh tidak mempengaruhi motivasi kerja penyuluh pertanian.

H1: Paling tidak faktor pendorong, faktor penghambat, faktor eksternal, atau faktor kompetensi penyuluh mempengaruhi motivasi kerja penyuluh pertanian.

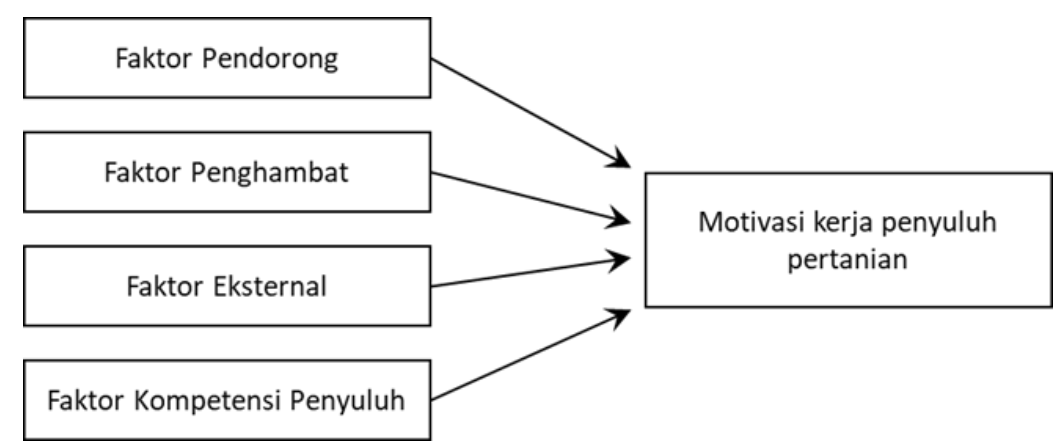

Gambar 2. Hipotesis model pengaruh faktor terhadap motivasi kerja penyuluh pertanian

2. Menyusun model diagram jalur berdasarkan variabel-variabel (Tabel 3) yang telah ditentukan dalam penelitian ini.

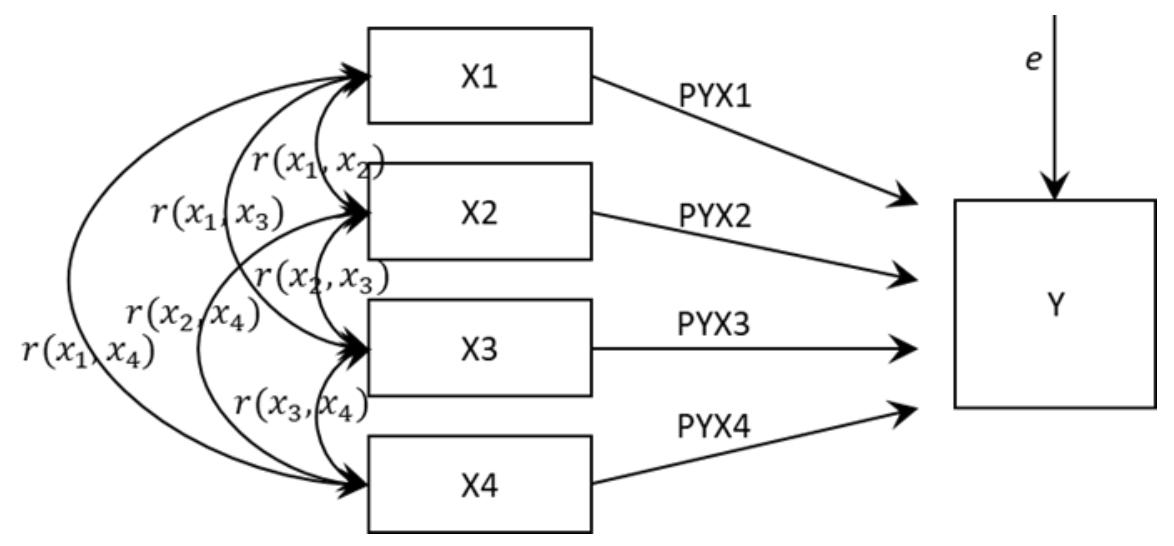

Gambar 3. Model diagram jalur dari variabel yang digunakan

3. Menentukan persamaan struktural $Y=P Y X 1+P Y X 2+P Y X 3+P Y X 4+e$.

4. Menghitung statistik analisis jalur (path analisis). Penelitian ini menghitung statistik analisis jalur dengan bantuan software SPSS Versi 21.

\section{HASIL DAN PEMBAHASAN}

Hasil analisis menunjukkan bahwa tidak terdapat pengaruh langsung faktor pendorong terhadap motivasi penyuluh, artinya motivasi penyuluh Malang Raya dalam melaksanakan tugas pokok dan fungsinya khususnya dalam berafiliasi dan berprestasi tetap baik walau tidak ada faktor pendorong. Fakta menunjukkan bahwa $51 \%$ penyuluh menyatakan telah mendapatkan upah atau gaji secara adil (Gambar 4.a). Gaji atau upah yang diterima penyuluh secara pasti tiap bulannya telah sesuai dengan apa yang dijanjikan dalam peraturan pemerintah, sehingga dalam kasus ini upah dan gaji tidak berpengaruh terhadap motivasi penyuluh. 
Salah satu faktor pendorong motivasi kerja penyuluh yaitu kesempatan untuk maju (Pratama, 2018, Gunawan dkk., 2017). Penyuluh menjalankan tupoksinya dengan mendapat kesempatan untuk maju atau berkembang/meningkatkan profesionalisme dalam bekerja. Sebanyak $67 \%$ penyuluh menyatakan bahwa kesempatan untuk maju adalah baik (Gambar 4.b).

Salah satu faktor pendorong dalam motivasi penyuluh yaitu suasana yang membuat rasa aman dari gangguan selama bekerja. Fakta menunjukkan bahwa $79 \%$ penyuluh, menyatakan aman bekerja sebagai penyuluh dalam melaksanakan tupoksinya, dan tidak ada satu pun penyuluh yang merasa tidak nyaman dalam bekerja menjadi seorang penyuluh (Gambar 4.c). Hal ini menunjukkan bahwa keamanan bekerja tidak mempengaruhi motivasi penyuluh dalam melaksanakan tugas pokok dan fungsi sebagai penyuluh.

Tempat kerja yang baik merupakan faktor pendorong dalam motivasi seorang penyuluh. Terdapat $79 \%$ respoden menyatakan setuju bahwa tempat kerja mereka baik (Gambar 4.d). Dengan demikian tempat kerja yang baik tidak mempengaruhi motivasi penyuluh dalam melaksanakan tugas pokok dan fungsi sebagai penyuluh. Hal ini dikarenakan tempat kerja penyuluh pertanian di seluruh Indonesia telah disediakan dengan standar yang relatif sama, yaitu di Balai Penyuluh Pertanian yang berdomisili di kecamatan.

Salah satu faktor pendorong kinerja penyuluh yaitu bagaimana seorang penyuluh diperlakukan dalam pekerjaannya. Berdasarkan (Gambar 4.e), terdapat 65\% penyuluh yang menyatakan setuju telah mendapatkan perlakuan yang wajar dari pemerintah dalam menjalankan tupoksinya sebagai penyuluh. Dengan demikian perlakuan yang wajar tidak mempengaruhi motivasi penyuluh dalam melaksanakan tugasnya.

Penghargaan atau pengakuan atas prestasi merupakan salah satu faktor penting dalam mendorong peningkatan kinerja penyuluh. Seorang penyuluh yang dihargai dengan baik akan merasa bahwa mereka telah dihargai atas apa yang mereka kerjakan. Namun demikian tidak mempengaruhi motivasi penyuluh dalam melaksanakan tugasnya sebagai seorang penyuluh. Penyuluh termotivasi bekerja jika petani menerimanya dan membutuhkan penyuluh dalam memecahkan permasalahan yang dihadapi penyuluh.

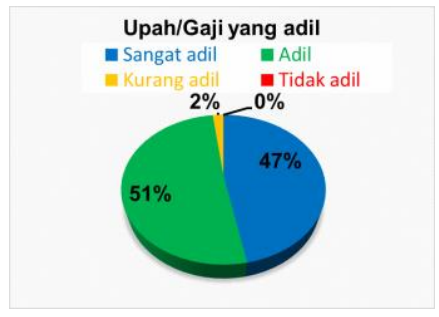

(a)

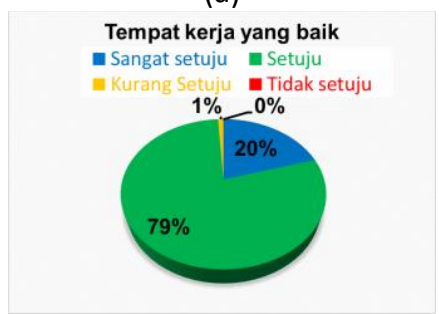

(d)

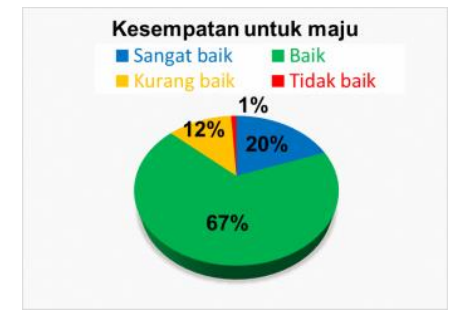

(b)

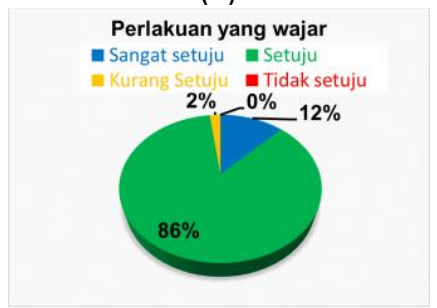

(e)

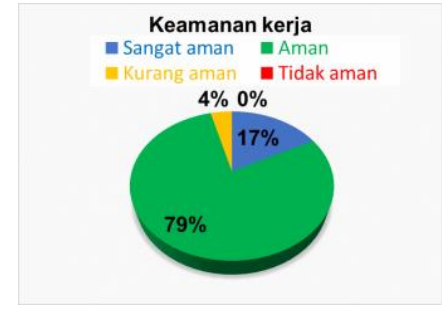

(c)

Perlakuan atas prestasi - Sangat setuju $=$ Setuju

- Sangat setuju

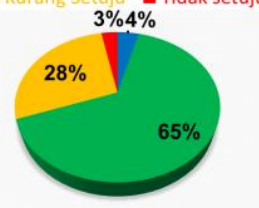

(f)

Gambar 4. Jawaban responden terhadap faktor pendorong

Berdasarkan hasil analisis, nilai signifikasi pengaruh faktor pendorong terhadap motivasi penyuluh sebesar 0,888 . Nilai tersebut lebih besar dari $\alpha 0,05$ yang mengindikasikan tidak terdapat pengaruh langsung faktor pendorong terhadap motivasi penyuluh (Tabel 4). Dengan demikian Ho yang menyatakan tidak terdapat faktor pendorong terhadap motivasi penyuluh, diterima. Sementara Ha yang menyatakan terdapat pengaruh faktor pendorong terhadap motivasi penyuluh, ditolak.

Faktor penghambat mempunyai nilai signifikansi pengaruh terhadap motivasi penyuluh sebesar 0,231 yang melebihi nilai $\alpha=0,05$ (Tabel 4). Hal ini mengindikasikan faktor penghambat tidak mempengaruhi langsung terhadap motivasi penyuluh. Hal ini mempunyai makna bahwa motivasi penyuluh di Malang Raya tetap berafiliasi dan berprestasi walaupun terdapat faktor penghambat.

Tabel 4. Pengaruh langsung faktor-faktor terhadap motivasi kerja

\begin{tabular}{lcc}
\hline \multicolumn{1}{c}{ Faktor } & Standardized Coefficients (Beta) & Sig \\
\hline Pendorong & 0,012 & 0,888 \\
Penghambat & $-0,108$ & 0,231 \\
Eksternal & 0,355 & 0,002 \\
Kompetensi Penyuluh & 0,292 & 0,008 \\
\hline
\end{tabular}

Sumber: Analisis data primer, 2019 (diolah) 
Tidak adanya penghargaan atau pengakuan atas prestasi merupakan salah satu faktor penghambat yang mempengaruhi motivasi penyuluh. Karena pada dasarnya seorang penyuluh yang dihargai dengan baik akan merasa bahwa mereka telah dihargai atas apa yang mereka kerjakan, dan pengakuan prestasi tersebut merupakan salah satu alat untuk meningkatkan motivasi kinerja penyuluh. Penghargaan merupakan hal yang sangat penting untuk mendorong motivasi penyuluh dalam melaksanakan tupoksinya. Peningkatan motivasi penyuluh menyangkut kemampuan diri penyuluh menjalankan fungsi penyuluhan berdasarkan Undang-undang No. 16 tahun 2006 untuk dapat diterapkan dalam kegiatan penyuluhan sehingga petani merasa puas dengan kegiatan penyuluhan. Hal ini dikarenakan penyuluh sebagai ujung tombak pembangunan pertanian, meskipun di era globalisasi setiap orang bisa mendapatkan informasi secara bebas namun keberadaan penyuluh masih tetap dibutuhkan. Penyuluh dituntut untuk terus meningkatkan kapasitasnya, jika tidak maka penyuluh akan ditinggalkan oleh petani.

Tempat kerja merupakan salah satu faktor penting dalam meningkatkan motivasi penyuluh. Dukungan tempat kerja yang baik akan meningkatkan motivasi penyuluh untuk bekerja lebih baik lagi. Tempat kerja merupakan sarana dalam melaksanakan kegiatan maka tempat kerja penyuluh pertanian di kecamatan dipusatkan di BPP. Mengacu Surat Edaran Menteri Dalam Negeri Nomor: 520/2017 dinyatakan bahwa BPP adalah Kelembagaan Penyuluhan Pertanian di kecamatan, merupakan suatu unit kerja non-struktural, yang berfungsi sebagai tempat pertemuan bagi para penyuluh pertanian, petani dan pelaku usaha dipimpin oleh Koordinator Penyuluh Pertanian. BPP mempunyai peran strategis yang harus mampu mengkoordinasikan, mensinergikan dan menyelaraskan kegiatan pembangunan pertanian pada Wilayah Kerja Penyuluhan Pertanian di Kecamatan dengan pihak terkait lainnya.

Dukungan dari atasan adalah hal penting untuk meningkatkan motivasi penyuluh. Dukungan dari atasan dapat meningkatkan motivasi penyuluh. Dukungan instansi pemerintah daerah (Dinas Pertanian dan ketahanan pangan) dinilai cukup baik. Hasil penelitian menunjukkan bahwa baik penyuluh PNS maupun penyuluh THL menganggap tingkat peran instansi pemerintah cukup baik. Keikutsertaan lembaga pemerintah dalam mendukung penyuluhan dalam melaksanakan kegiatan penyuluhan.

Nilai signifikasi pengaruh faktor eksternal terhadap motivasi penyuluh sebesar 0,002 . Nilai tersebut lebih kecil dari a 0,05 yang mengindikasikan terdapat pengaruh langsung faktor eksternal terhadap motivasi penyuluh. Dengan demikian Ho yang menyatakan tidak terdapat pengaruh faktor eksternal terhadap motivasi penyuluh, ditolak. Sementara Ha yang menyatakan terdapat pengaruh faktor eksternal terhadap motivasi penyuluh, diterima. Hasil analisis menunjukkan bahwa terdapat pengaruh langsung faktor eksternal terhadap motivasi penyuluh, Hal ini menunjukkan bahwa faktor eksternal seperti fasilitas kerja yang baik, dukungan tertib administrasi, kondisi lingkungan kerja yang nyaman, keterjangkauan lokasi penyuluhan dan petani, dan partisipasi masyarakat yang tinggi dalam kegiatan penyuluhan akan meningkatkan motivasi penyuluh dalam berafiliasi dan berprestasi dalam bekerja.

Fasilitas kerja merupakan salah satu faktor penting yang mempengaruhi motivasi penyuluh dalam melaksanakan tugasnya sebagai penyuluh. Dengan adanya fasilitas kerja yang baik dapat memotivasi penyuluh untuk bekerja lebih baik lagi. Fasilitas kerja yang baik tentu harus didukung oleh kelembagaan penyuluhan yang baik pula. Hattab (2014) mengungkapkan bahwa peningkatan dukungan kelembagaan penyuluhan dan kelembagaan lain dapat dilakukan dengan pendekatan yang tepat sesuai dengan karakteristik khalayak sasaran (kesesuaian informasi, ketepatan metode, penggunaan berbagai teknik penyuluhan, serta penggunaan media dalam penyuluhan) serta ketersediaan programa penyuluhan, kemudahan akses, dukungan fasilitas yang diperlukan, dan pelaksanaan program.

Dukungan administrasi yang lengkap dapat memperlancar kegiatan penyuluhan. Dukungan administrasi penyuluhan mempengaruhi motivasi penyuluh untuk meningkatkan kompetensinya sebagai penyuluh. Dukungan administrasi yang baik ditentukan pula oleh kompetensi penyuluh dalam mengumpulkan data-data potensi petani yang dibinanya. Sumardjo (2008) menyatakan bahwa kompetensi adalah kemampuan dan kewenangan yang dimiliki seseorang untuk melakukan suatu pekerjaan, yang didasari oleh pengetahuan, keterampilan dan sikap sesuai dengan unjuk kerja yang ditetapkan (standar). Dengan kompetensi yang dimiliki penyuluh dan administrasi yang rapi maka kinerja penyuluh dapat meningkat.

Kondisi lingkungan kerja yang baik dapat meningkatkan motivasi penyuluh dalam bekerja. Motivasi penyuluh yang baik antara lain diukur dari tingkatan kegiatan penyuluhan yang didasari dan dilaksanakan dengan pendekatan partisipatif. Penilaian kinerja penyuluh meliputi aspek: identifikasi kebutuhan dan penyusunan rencana kerja, pengembangan kelompok, pelaksanaan proses pembelajaran dan pengembangan jejaring kerja.

Keterjangkauan lokasi wilayah binaan penyuluh mempengaruhi motivasi penyuluh dalam melaksanakan tugasnya sebagai seorang penyuluh. Dalam melaksanakan kegiatan seorang penyuluh akan ditempatkan atau diberikan wilayah kerja penyuluhan pertanian (WKPP). Dalam penetapan wilayah kerja tersebut tentu harus dipertimbangkan keterjakauannya. Berdasarkan hasil analisis data di lapangan, wilayah kerja penyuluh pertanian di Malang Raya relatif dapat dijangkau dengan baik. Semakin mudah lokasi dapat dijangkau maka penyuluh semakin termotivasi untuk melakukan kegiatan binaan ke kelompok tani. Walaupun demikian masih terdapat beberapa desa yang penyuluh itu sendiri tidak tinggal di desa tersebut. Diperlukan waktu yang cukup lama untuk sampai ke wilayah kerja, hambatan sarana transportasi dan medan jalan yang dilalui ke rumah/lahan petani serta penyuluh harus menyesuaikan dengan waktu luang petani sehingga penyuluh harus menyesuaikan kondisi yang ada. Namun demikian penyuluh tetap 
termotivasi untuk melakukan kunjungan ke kelompok tani binaan karena transportasi yang relatif mudah, dan partisipasi petani yang baik dalam setiap kegiatan penyuluhan.

Partisipasi petani mempengaruhi motivasi penyuluh dalam melaksanakan kegiatan penyuluhan. Peran kelompok dalam membantu mengakses program pemerintah untuk peningkatan kesejahteraan petani, harus melalui kelompok tani. Upaya mempermudah pembinaan, pendampingan dan penyaluran bantuan program pemerintah dilakukan melalui kelompok tani/gapoktan. Petani menyatakan bahwa untuk memperoleh bantuan harus menjadi anggota kelompok, bila tidak berkelompok maka sulit mendapatkan bantuan. Oleh sebab itu petani merasa bahwa kelompok berperan dalam mengakses bantuan atau program-program pemerintah. Dukungan kelompok tani tidak terlepas dari aktivitas kelompok dalam berperan aktif menggerakkan anggotanya. Oleh karena itu, motivasi petani dapat ditumbuhkan dari ketertarikan anggota terhadap manfaat berkelompok. Ketertarikan anggota terhadap manfaat berkelompok tergolong kategori sangat tertarik. Manfaat yang paling besar nilainya pada ketertarikan bahwa berkelompok dapat meningkatkan keakraban dan rasa kekeluargaan antara sesama anggota

Nilai signifikasi pengaruh faktor kompetensi penyuluh terhadap motivasi penyuluh sebesar 0,008 . Nilai tersebut lebih kecil dari $\alpha$ 0,05 yang mengindikasikan terdapat pengaruh langsung faktor kompetensi penyuluh terhadap motivasi penyuluh. Dengan demikian Ho yang menyatakan tidak terdapat pengaruh faktor kompetensi penyuluh terhadap motivasi penyuluh penyuluh, diterima. Sementara Ha yang menyatakan terdapat pengaruh faktor kompetensi penyuluh terhadap motivasi penyuluh, ditolak. Pengaruh langsung faktor kompetensi penyuluh terhadap motivasi penyuluh, artinya semakin tinggi kompetensi yang dimiliki penyuluh di Malang Raya dalam hal penguasaan teknologi, pengetahuan kreativitas yang tinggi tidak akan meningkatkan motivasi penyuluh dalam berafiliasi dan berprestasi dalam bekerja.

Kompetensi kerja penyuluh dalam hal penguasaan teknologi merupakan suatu keterampilan yang dimiliki oleh seseorang penyuluh terhadap segala aspek pekerjaan yang akan dijalankan dan keterampilan tersebut membuatnya merasa mampu untuk bisa mencapai berbagai tujuan dalam pekerjaannya. Pada saat ini penguasaan teknologi sangat penting dalam menyampaikan informasi ataupun melakukan berbagai jenis pekerjaan termasuk dalam kegiatan penyuluhan, baik teknis, IT, metodologi dan sosial. Terdapat $57 \%$ penyuluh menyatakan kompetensi penyuluh dalam penguasaan teknologi sangat menguasai (Gambar 5.a). Hal ini menjelaskan bahwa kompetensi penyuluh dalam penguasaan teknologi sudah baik.

Kompetensi penyuluh sangat penting terutama dalam hal pengetahuan dalam pekerjaannya baik dalam kegiatan penyuluhan, secara teknis, penguasaan teknologi, metodologi penyuluhan dan pengetahuannya tentang sosial masyarakat khususnya di wilayah kerjanya. Pengetahuan yang dimiliki sangat penting dalam membentuk tindakan seorang penyuluh. Terdapat $65 \%$ penyuluh yang menyatakan kompetensi penyuluh sangat menguasai pengetahuan (Gambar 5b).

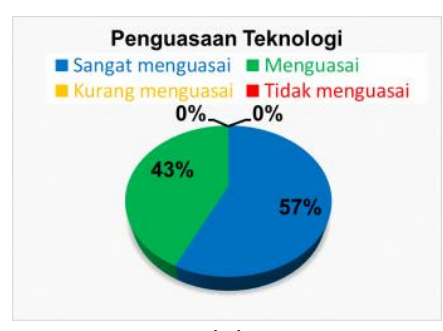

(a)

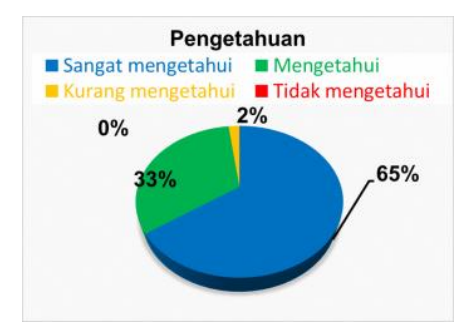

(b)

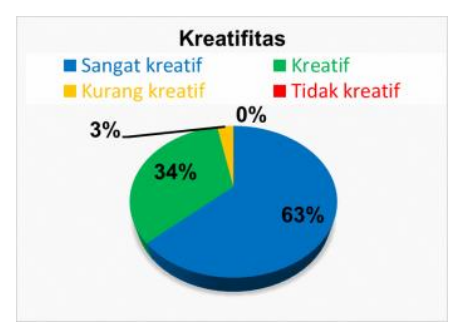

(c)

Gambar 5. Jawaban rensponden terhadap kompetensi penyuluh

Kreativitas penyuluh salah satunya dapat dilihat dari kemampuannya dalam mengatasi masalah petani. Kemampuan mengatasi masalah merupakan kemampuan personal yang juga sangat penting dimiliki oleh penyuluh. Banyaknya permasalahan hidup yang dihadapi sering kali menjadi beban dan dapat mengganggu kegiatan petani dalam berusaha tani. Kemampuan penyuluh ini, merupakan kemampuan yang dimiliki oleh setiap individu. Kreativitas dalam memecahkan permasalahan Bersama-sama petani sangat diperlukan, Hal ini dapat membantu petani untuk berkreativitas menemukan permasalahannya sendiri dalam berusaha tani dan akhirnya dapat menyelesaikan masalah yang dihadapi petani. Kemampuan mengatasi masalah tersebut dapat menunjang keberhasilan dan kemandirian petani. Kemampuan penyuluh dalam mengetahui, menguasai, memahami dan melaksanakan kaidah-kaidah teknis pengelolaan akan meningkatkan kemandirian dan keberhasilan petani (Suprayitno 2011).

Dorongan berprestasi (Gambar 6.a) menjadi motivasi penyuluh dalam melakukan tugasnya. Penyuluh melakukan afiliasi (Gambar 6.b) sebagai salah satu motivasi kerjanya. 


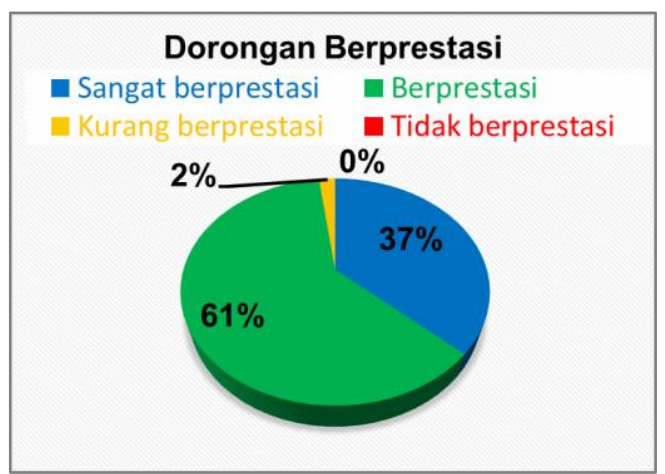

(a)

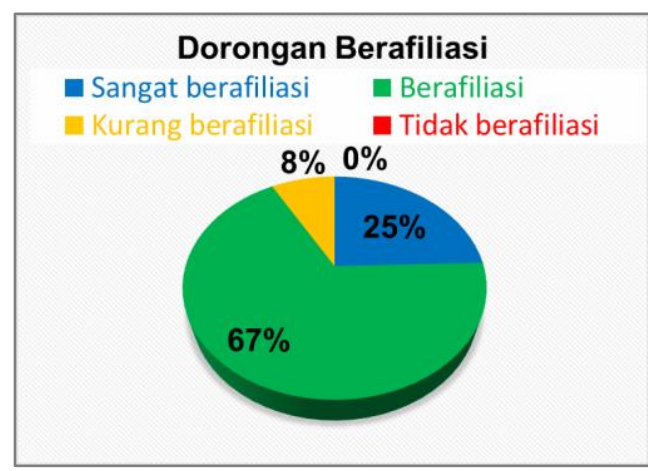

(b)

Gambar 6. Jawaban responden tentang motivasi penyuluh

Faktor pendorong, faktor penghambat, faktor eksternal, dan faktor kompetensi penyuluh mempunyai pengaruh terhadap motivasi penyuluh sebesar $26,9 \%$ (Tabel 5). Hal ini menunjukkan bahwa model hanya mampu menerangkan keragaman data sebesar 26,9\%, sedangkan 73,1\% keragaman data lainnya dipengaruhi oleh faktor lain atau nilai error. Nilai e $=\mathrm{V}(1-0,269)$ sebesar 0,85 . Model analisis jalur untuk pengaruh langsung faktor pendorong, faktor penghambat, faktor eksternal, dan faktor kompetensi penyuluh terhadap motivasi penyuluh disajikan pada Gambar 7.

Tabel 5. Statistik pengaruh faktor pendorong, faktor penghambat, faktor eksternal, faktor kompetensi penyuluh terhadap motivasi penyuluh.

\begin{tabular}{ccccc}
\hline Model & $\mathrm{R}$ & $\mathrm{R}$ Square & $\begin{array}{l}\text { Adjusted } \\
\mathrm{R} \text { Square }\end{array}$ & Std. Error of the Estimate \\
\hline Motivasi penyuluh & $0.519^{(\mathrm{a})}$ & 0.269 & 0.230 & 3.35015 \\
\hline
\end{tabular}

Keterangan: ${ }^{(\text {a) }}$ Predictors (Constant), Motivasi, Faktor Penghambat, Faktor Pendorong, Faktor kompetensi penyuluh, faktor eksternal

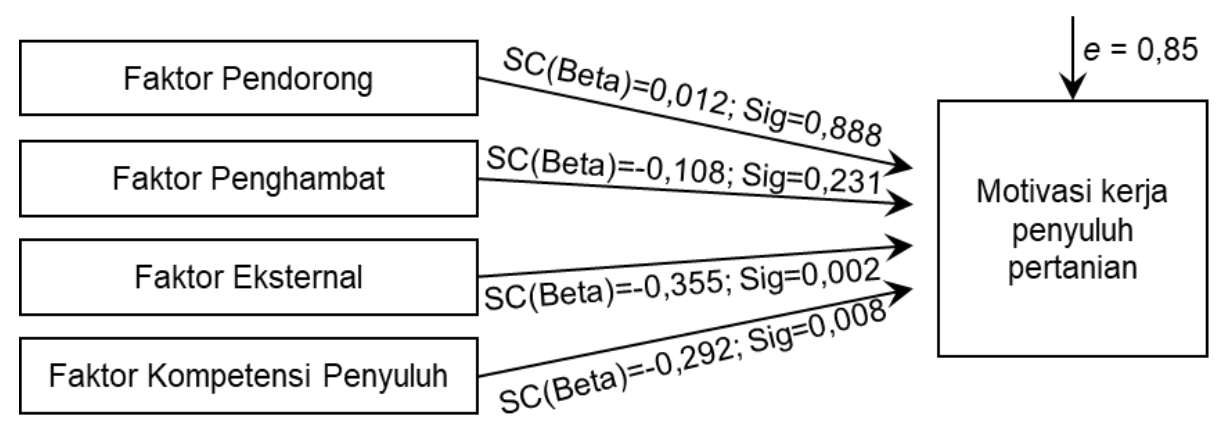

Gambar 7. Model pengaruh langsung faktor pendorong, faktor penghambat, faktor eksternal, dan faktor kompetensi penyuluh terhadap motivasi penyuluh

\section{KESIMPULAN}

Era revolusi industri 4.0 merupakan tantangan bagi penyuluh dalam melakukan adaptasi dengan situasi berbasis teknologi digital dan sistem informasi. Dorongan penyuluh untuk melakukan penyuluhan pada hakikatnya terselubung bagi yang bersangkutan, tetapi dapat ditelusuri melalui perilakunya. Penelusuran menemukan faktor-faktor yang mempengaruhi motivasi kerja penyuluh, yaitu faktor eksternal dan faktor kompetensi penyuluh. Sedangkan faktorfaktor yang tidak mempengaruhi secara langsung terhadap motivasi penyuluh adalah faktor pendorong dan faktor penghambat.

\section{DAFTAR PUSTAKA}

Amanah, S. (2014). Paradigma penyuluhan dan pendekatan pemberdayaan. Di dalam: Pemberdayaan sosial petaninelayan, keunikan agroekosistem, dan daya saing. Jakarta: Yayasan Pustaka Obor Indonesia.

Bahua, M.I. (2015). Penyuluhan dan pemberdayaan penyuluh Indonesia. Gorontalo (ID): Ideas Publishing. Retrieved from https://repository.ung.ac.id/get/karyailmiah/537/Penyuluhan-dan-Pemberdayaan-Petani-Indonesia.pdf Bahua, M. I. (2016). Kinerja penyuluh pertanian (Eds 1). Yogyakarta (ID): Deepublish. 
Dasli, A. P. E., Muljono, P., \& Susanto, D. (2015). Pemanfaatan cyber extension melalui telepon genggam oleh petani anggrek di Taman Anggrek Ragunan, Jakarta Selatan. Jurnal Penyuluhan, 11(2), $103-115$. https://doi.org/10.25015/penyuluhan.v11i2.10574

Dzakiroh, D., Wibowo, A., \& Ihsaniyatin, H. (2017). Sikap afektif penyuluh terhadap website cyber extension sebagai sumber informasi penyuluhan pertanian di Kabupaten Karanganyar. Jurnal Agritexts, 41(1), 16-31. https://jurnal.uns.ac.id/agritexts/article/view/18058

Elian, N., Lubis, D. P., \& Rangkuti, P. A. (2014). Internet ussage and agricultural information utilization by agricultural extension staff in Bogor District. Jurnal Komunikasi Pembangunan, 12(2), $104-109$. http://journal.ipb.ac.id/index.php/jurnalkmp/article/view/8666/pdf

Fatchiya, A., \& Amanah, S. (2016). Penerapan inovasi teknologi pertanian dan hubungannya dengan ketahanan pangan rumah tangga petani. Jurnal Penyuluhan, 12(2), 190-197. https://doi.org/10.25015/penyuluhan.v12i2.12988

Ghozali, I., dan Fuad. (2008). Structural Equation Modeling; Teori, Konsep dan Aplikasi dengan Lisrel 8.80. Semarang (ID): Badan Penerbit Universitas Diponegoro.

Gunawan, A., Machasin, M., \& Fitri, K. (2017). Pengaruh kompensasi dan pengembangan karir terhadap kepuasan kerja perawat yang dimediasi oleh motivasi kerja pada rumah sakit Bina Kasih Pekanbaru. JOMFEKON, 2(1). https://jom.unri.ac.id/index.php/JOMFEKON/article/view/13246

Kline, R. B. (2011). Methodology in the social sciences.principles and practice of structural equation modeling (3rd ed.). Canada (CA): Guilford Press.

Khan, G. F., Sarstedt, M., Shiau, W. L., Hair, J. F., Ringle, C. M., \& Fritze, M. P. (2019). Methodological research on partial least squares structural equation modeling (PLS-SEM). Internet Research, 29(3). https://www.emerald.com/insight/content/doi/10.1108/IntR-12-2017-0509/full/html

Listiana, I., Efendi, I., \& Rahmat, A. (2019). The behavior of extension agents in utilizing information and technology to improve the performance of extension agents in Lampung Province. In Journal of Physics: Conference Series (Vol. 1155, No. 1, p. 012004). IOP Publishing. https://iopscience.iop.org/article/10.1088/1742-6596/1155/1/012004/meta

Mulyandari, Sumardjo, Lubis, D. P., \& Panjaitan, N. K. (2011). Cyber extension as a communications media for vegetable farmer Empowerment. Journal of Agricultural Extension and Rural Development, 4(3), 77-84. https://academicjournals.org/journal/JAERD/article-abstract/43C25302914

Prasetyo, A. S., Aulia, A. N., \& Sinaga, A. S. (2020). Performance of agricultural extension workers in implementing urban agriculture programs in Banyumanik District, Semarang City, Indonesia. Journal of Socioeconomics and Development, 3(1), 29-36. https://doi.org/10.31328/jsed.v3i1.1315

Pratama, V. F. M. (2018). Motivasi kerja petugas pemadam kebakaran [Skripsi]. Malang (ID): University of Muhammadiyah Malang. http://eprints.umm.ac.id/id/eprint/38280

Praza, R. (2016). Optimalisasi cyber extension dalam pembangunan pertanian di era mea. Prosiding Semirata BKS-PTN Wilayah Barat Bidang Ilmu Pertanian, Lhokseumawe 04-06 Agustus 2016, 2(1), 200-204.

Purwatiningsih, N. A., Fatchiya, A., \& Mulyandari, R. S. H. (2018). Pemanfaatan internet dalam meningkatkan kinerja penyuluh pertanian di Kabupaten Cianjur.Jurnal Penyuluhan, 14(1), 79-91. Retrieved from http://dx.doi.org/10.25015/penyuluhan.v14i1.17173

Rochaeni, S., Ludiin, M. R., \& Ramly, M. (2019). The impact of task variety, career promotion, and reward to agricultural extension worker's performance. Archives of Business Research, 7(4). Retrieved from https://doi.org/10.14738/abr.74.6375

Roza, E., Rosnita, R., \& Restuhadi, F. (2018). Faktor-Faktor yang mempengaruhi kinerja penyuluh pertanian dan dampaknya terhadap produksi padi petani di Kabupaten Siak. Jurnal Pendidikan Ekonomi Dan Bisnis (PEKBIS), 10(1), 1-11. https://pekbis.ejournal.unri.ac.id/index.php/JPEB/article/download/5252/4925

Sarstedt, M., \& Cheah, J. H. (2019). Partial least squares structural equation modeling using smartpls: a software review. Journal of Marketing Analytics, 7(3), 196-202. https://doi.org/10.1057/s41270-019-00058-3

Sarwono, J. (2012). Mengenal PLS-SEM. Yogyakarta (ID): CV. Andi Offset.

Setiawan, I. (2012). Dinamika pemberdayaan petani: sebuah refleksi dan generalisasi di Jawa Barat. Bandung (ID): Widya Padjajaran.

Sumardjo (2008). Penyuluhan Pembangunan pilar: Pilar pendukung kemajuan dan kemandirian masyarakat dalam pemberdayaan manusia pembangunan yang bermartabat. Penyunting: Adjat Sudradjat dan Ida Yustina. Bogor (ID): Sydex Plus.

Suprayitno, A. (2011). Model peningkatan partisipasi petani sekitar hutan dalam mengelola hutan kemiri rakyat: kasus pengelolaan hutan kemiri kawasan pegunungan Bulusaruang Kabupaten Maros Sulawesi Selatan [Disertasi]. Institut Pertanian Bogor.

Tung, Lo Choi. (2011). The Impact of Entrepreneurship Education on Entrepreneurial Intention of Engineering Students. City University of Hongkong (HK): Run Run Show Library.

Wijaya, A. F., Kuntariningsih, A., Sarwono, S., \& Suryono, A. (2019). Role and contribution of vegetables in mitigating malnutrition through a sustainable food reserve program. International Journal of Vegetable Science, 1-11. https://doi.org/10.1080/19315260.2019.1703872 
Zulfikar. (2017). Persepsi penyuluh terhadap kompetensi penyuluh pertanian tanaman pangan di Kabupaten Aceh Utara [Tesis]. Institut Pertanian Bogor (ID): Bogor. https://repository.ipb.ac.id/handle/123456789/91398 